OPEN ACCESS

Edited by:

Jonathan G. Rudick,

Stony Brook University, United States

Reviewed by:

Mohammad Hasanzadeh,

Tabriz University of Medical

Sciences, Iran

Khurshid Ayub,

COMSATS University

Islamabad, Pakistan

*Correspondence:

Mahdieh Darroudi

M.darroudi@alzahra.ac.ir

Ghodsi Mohammadi Ziarani gmohammadi@alzahra.ac.ir

Specialty section: This article was submitted to

Organic Chemistry,

a section of the journal

Frontiers in Chemistry

Received: 05 November 2020 Accepted: 10 December 2020

Published: 02 February 2021

Citation:

Darroudi M, Mohammadi Ziarani G, Bahar S, Ghasemi JB and Badiei A

(2021) Lansoprazole-Based

Colorimetric Chemosensor for Efficient

Binding and Sensing of Carbonate

Ion: Spectroscopy and DFT Studies.

Front. Chem. 8:626472.

doi: 10.3389/fchem.2020.626472

\section{Lansoprazole-Based Colorimetric Chemosensor for Efficient Binding and Sensing of Carbonate lon: Spectroscopy and DFT Studies}

\author{
Mahdieh Darroudi ${ }^{1 *}$, Ghodsi Mohammadi Ziarani ${ }^{1 *}$, Shahriyar Bahar ${ }^{1}$, Jahan B. Ghasemi ${ }^{2}$ \\ and Alireza Badiei ${ }^{2}$ \\ ${ }^{1}$ Department of Chemistry, Faculty of Physics and Chemistry, Alzahra University, Tehran, Iran, ${ }^{2}$ School of Chemistry, College \\ of Science, University of Tehran, Tehran, Iran
}

The new benzimidazole based receptor Lansoprazole has been used to detect carbonate anion by naked-eye and Uv-Vis spectroscopy. This receptor revealed visual changes with $\mathrm{CO}_{3}^{2-}$ anion in ethanol. No detectable color changes were observed upon the addition of any other tested anions. The lansoprazole chemosensor selectively recognizes $\mathrm{CO}_{3}^{2-}$ ion over the other interference anions in the ethanol, followed by deprotonation and reflected 1:1 complex formation between the receptor and the carbonate ion. Lansoprazole exhibits splendid selectivity toward carbonate ion via a visible color change from colorless to yellow with a detection limit of $57 \mu \mathrm{M}$. The binding mode of $\mathrm{CO}_{3}^{2-}$ to receptor $\mathbf{L}$ is supported by Density Functional Theory calculation. Moreover, this receptor shows a practical visible colorimetric test strip for the detection of carbonate ions. The transition states calculation demonstrates the occurrence of reaction from $\mathbf{L}$ to $\mathbf{L}-\mathrm{CO}_{3}^{2-}$ after overcoming an energy barrier of $10.1 \mathrm{kcal} / \mathrm{mol}$, and there is considerable interaction energy between $\mathbf{L}$ and $\mathrm{CO}_{3}^{2-}(94.9 \mathrm{~kJ} / \mathrm{mol})$, both of which confirmed that receptor $\mathbf{L}$ has high sensitivity and selectivity to the carbonate ion. The theoretical studies were performed to acquire an electronic description of the complexation mechanism by $\mathrm{CO}_{3}^{2-}$ as well as to study bonding and structure in the complex. The optimized structures and binding mechanisms were supported with a high correlation and agreement by spectroscopy and DFT calculations.

Keywords: lansoprazole, benzimidazole derivatives, chemosensor, carbonate ion, UV-Vis studies, density functional theory

\section{INTRODUCTION}

Developing anionic chemosensors is one of the most important topics nowadays. The optical sensor systems based on light usage as a most valuable and versatile output signal and several chromatographic and fluorogenic anion sensors have been recently established (Fabbrizzi et al., 2001, 2003; Ghorai et al., 2016a; Iqbal et al., 2018; Isaac et al., 2018; Wasim et al., 2018; Mahmudi et al., 2019; Mobed et al., 2019). Carbonate is one of these anions which is extensively used in the production of cosmetics, rubber, glass, printing ink, rayon, food, toothpaste, and rechargeable Liion batteries (Tas, 2009; Zhao et al., 2014; Ghorai et al., 2016a; Kordi et al., 2019; Darroudi et al., 2020). Moreover, carbonate has a pivotal role in agricultural planning, hydrology, soil, and geology 


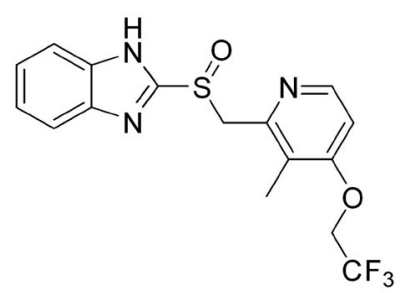

FIGURE 1 | 2-[[[3-methyl-4-(2,2,2,-trifluoroethoxy)-2-pyridil]sulfinyl-1Hbenzimidazole(Lansoprazole).

science (Choi et al., 2002; Zougagh et al., 2005; Morris et al., 2010). Regardless of these broad applications in different industries, $\mathrm{CO}_{3}^{2-}$ ion is a toxic chemical in high dosages as abdominal pain, collapse, and even death, thus developing a cost-effective and straightforward chemosensor for $\mathrm{CO}_{3}^{2-}$ ion is vital (Jain et al., 2006; Abramova et al., 2010). Some analytical procedures have been established for $\mathrm{CO}_{3}^{2-}$ ion detection, including continuous-flow, $\mathrm{pH}$-ion sensitive fieldeffect transistor (Morf et al., 1989; Tsukada et al., 1990; Meruva and Meyerhoff, 1998), electrochemical (Lee et al., 2005), FT-IR spectroscopy (Burt and Rau, 1994), and chromo ionophore based optodes, etc. (Morf et al., 1989; Burt and Rau, 1994; Zougagh et al., 2005). However, these procedures are naked-eye-invisible and also time-consuming in most cases (García-Acosta et al., 2007; Movassagh et al., 2013; Ghorai et al., 2016a; Rouh et al., 2018; Smyth et al., 2020). While many probes have been described for the detection of various anions incorporate to acetate, sulfide, fluoride, and cyanide (Kondo and Takai, 2013; Reena et al., 2013; Tang et al., 2013, 2015; Zhang et al., 2013; Zheng et al., 2013; Kaur et al., 2015), limited chemosensors have been reported for $\mathrm{CO}_{3}^{2-}$ ion (Hennrich et al., 2001; Rice, 2008; Han et al., 2010; Vaněk et al., 2013).

On the other hand, one of the known aza heterocyclic structures in medicinal chemistry is benzimidazole scaffold, which has recently taken a great amount of attention in the scientific fields (Zhukova and Mamedov, 2017; Mostarda et al., 2019) because of their biological activities such as antibacterial (Xu et al., 2013), antifungal (Patel et al., 2014), antiviral (Monforte et al., 2008), antidiabetic (Liu et al., 2011), analgesic (Smith et al., 2008), and anticancer (Smith et al., 2008). Furthermore, benzimidazole-containing scaffolds, such as Lansoprazole currently is in use for the treatment of gastroesophageal reflux and ulcer disease (Gremse, 2001; Miyashita et al., 2013; Shin and Kim, 2013; Yu et al., 2015; Estrada-Ortiz et al., 2019). The generic name of Lansoprazole is 2-[[[3-methyl4-(2,2,2,- trifluoroethoxy)-2-pyridil] sulfinyl-1H-benzimidazole (Figure 1). To date, several fluorescents and UV-Vis sensors have been designed and reported, which some of them are benzimidazole-based, for various cations (Patel et al., 2013; Zhong et al., 2014; He et al., 2015; Maji et al., 2017; Liu C. et al., 2020) and anions (Yu et al., 2007; Zhang and Yu, 2017; Karuk Elmas et al., 2018; Ko et al., 2019; Liu F. et al., 2020; Tian and Li, 2020). Some carbonate chemosensors have been developed in recent years due to their rapidity, high sensitivity, and selectivity. However, some of the prepared sensors have much more detection limit to $\mathrm{CO}_{3}^{2-}$ ion detection in high sensitivity, most of these chemosensors are difficult to prepare, or the reactions are not cost-effective (Ghorai et al., 2016b; Tavallali et al., 2016, 2019; Karuk Elmas et al., 2018; Kahriman et al., 2019; Naderi et al., 2019; Singh et al., 2019; Morikawa et al., 2020; Velmurugan et al., 2020). Herein, we proposed a nakedeye chemosensor, which has some superior as a simple process, biocompatibility, efficiency, side effects on the body, and rapid response time. As a part of our ongoing research on the design of chemosensors (Karimi et al., 2017; Shiravand et al., 2018, 2020; Ahmadi et al., 2019; Arab et al., 2019; Kordi et al., 2019), we report the study of a chemosensor (L) for efficient sensing of carbonate ion over other ions by UV-Visible spectroscopy and remarkable colorimetric responses in the solution. The chemosensor $\mathbf{L}$ detected $\mathrm{CO}_{3}^{2-}$ ion by an alteration in absorbance accompanied by an instantaneous color change from colorless to yellow.

\section{MATERIALS AND METHODS}

\section{Materials and Instruments}

All the commercial-grade chemicals and reagents and all organic solvents were purchased from Sigma-Aldrich company and were used without further purifications. Stock solutions of all metal ions were prepared using their nitrate salts purchasing from Merck company. Also, Stock solutions of all anions were prepared using their sodium salts purchasing from Merck company. All the UV-Vis absorption spectra were recorded on Analytik Jena Specord S600 Spectrophotometer using a $10 \mathrm{~mm}$ path length quartz cuvette.

\section{UV-Vis Studies}

The anion recognition studies were performed at $25 \pm 1 \mathrm{C}$, and before recording any spectrum, sufficient time was given to ensure the solution uniformity. The UV-Vis spectra of chemosensor $\mathbf{L}\left(1 \times 10^{-4} \mathrm{~mol} \mathrm{~L}^{-1}\right)$ probe was evaluated with the addition of different anions such as $\mathrm{Br}^{-}, \mathrm{CH}_{3} \mathrm{COO}^{-}, \mathrm{Cl}^{-}$, $\mathrm{CN}^{-}, \mathrm{CO}_{3}^{2-}, \mathrm{Cr}_{2} \mathrm{O}_{7}^{2-}, \mathrm{F}^{-}, \mathrm{HPO}_{4}^{2-}, \mathrm{HSO}_{3}^{-}, \mathrm{I}^{-}, \mathrm{NO}_{2}^{-}, \mathrm{NO}_{3}^{-}, \mathrm{OH}^{-}$, $\mathrm{SCN}^{-}$, and $\mathrm{SO}^{2-}$ with the concentration of $1 \times 10^{-2} \mathrm{~mol} \mathrm{~L}^{-1}$. Among all studied anions, only carbonate ion could impose UVVis absorption of chemosensor $\mathbf{L}$, which led to color change as a colorimetric sensor for $\mathrm{CO}_{3}^{2-}$ ion, as shown in Figure 2. However, upon the $\mathrm{CO}_{3}^{2}$, a strong red-shift on the absorption is observed; while, the other anions affect slightly.

\section{Interfering Anions}

The sensor competition test of chemosensor $\mathbf{L}$ was investigated at $350 \mathrm{~nm}$ via the addition of $\mathrm{CO}_{3}^{2-}\left(1 \times 10^{-2} \mathrm{~mol} \mathrm{~L}^{-1}, 100 \mu \mathrm{l}\right)$ and other anions $\left(1 \times 10^{-2} \mathrm{~mol} \mathrm{~L}^{-1}, 100 \mu \mathrm{l}\right)$ to chemosensor $\mathbf{L}$ $\left(1 \mathrm{~mL}, 1 \times 10^{-4} \mathrm{~mol} \mathrm{~L}^{-1}\right)$ transferring into a cell. After mixing them for a few seconds, the UV-Vis spectra were recorded at room temperature. 


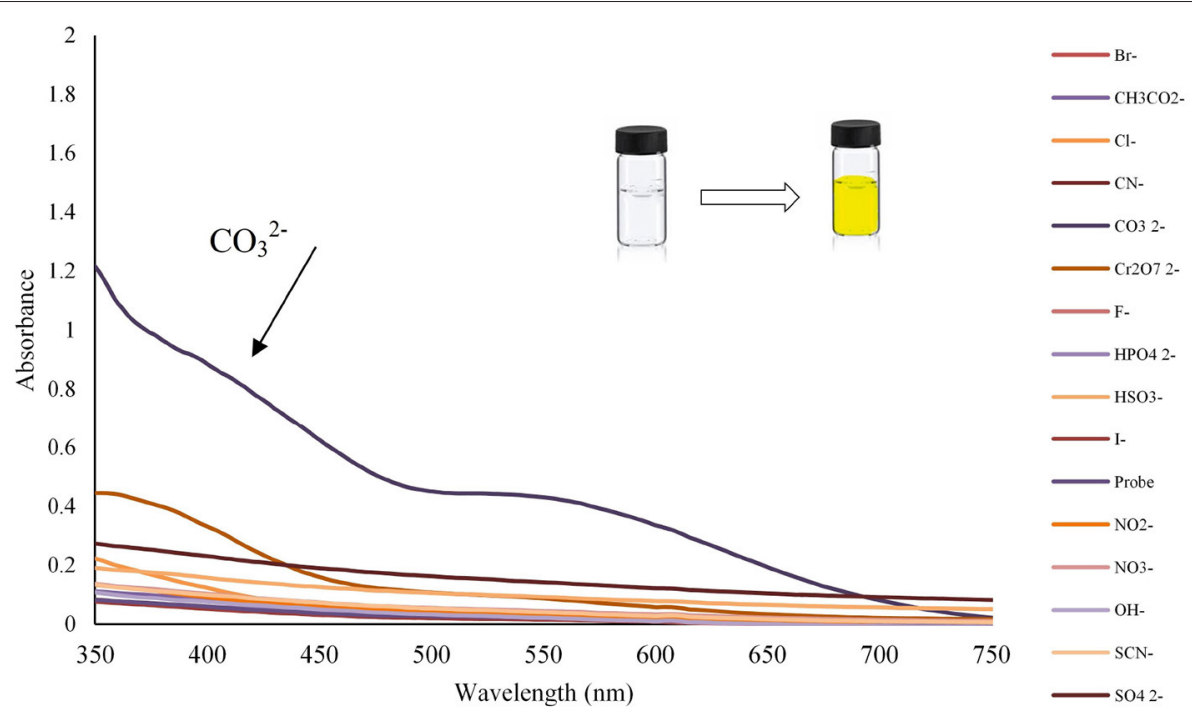

FIGURE 2 | Change in absorption spectra and color changes of benzimidazole $\mathbf{L}(1 \mathrm{~mL}, 0.0001 \mathrm{M})$ after addition of different anions (100 $\mu \mathrm{L}, 0.01 \mathrm{M})$ in ethanol (pH = 10.2).

\section{Titration Experiments}

The titration test was performed by adding the different concentration of carbonate ion $\left(1 \times 10^{-2} \mathrm{~mol} \mathrm{~L}^{-1}\right)$ to chemosensor $\mathbf{L}\left(1 \times 10^{-4} \mathrm{~mol} \mathrm{~L}^{-1}\right)$. The mixture was transferred into a quartz cell. Then a certain amount of $\mathrm{CO}_{3}^{2-}$ ion from 0 to $1,000 \mu \mathrm{l}\left(1 \times 10^{-2} \mathrm{~mol} \mathrm{~L}^{-1}\right)$ was added to the chemosensor $\mathrm{L}$ probe solution. The UV-Vis absorption spectra were recorded after $1 \mathrm{~min}$ at room temperature.

\section{Computational}

All calculations were carried out by DFT theory with B3LYP (Hay and Wadt, 1985) functionals as implemented in the Gaussian 09 program package (Robert, 1990). The geometries of all transition states (TSs) and ground states (GSs) were optimized utilizing 6-311+G(2d,2p) basis set (Hay and Wadt, 1985). Solvent effects were considered using CPCM calculations in the solvents (MacGregor, 1967; Luzar and Stefan, 1990; Klamt and Schüürmann, 1993; Andzelm et al., 1995; Barone and Cossi, 1998; Cossi et al., 2003; Jie and Guo-Zhu, 2013). On the basis of the optimized geometries, all energies were corrected with single point dispersion effect using the DFT-D2 method of Grimme (Grimme, 2006), as recent reports have shown that inclusion of these effects can significantly improve the accuracy of the B3LYP method (Xu et al., 2012).

\section{RESULTS AND DISCUSSION}

\section{UV-Vis Analysis}

The detecting anion ability of Lansoprazole could be evaluated in ethanol by UV-Vis absorption spectra toward a wide range of anions including $\mathrm{Br}^{-}, \mathrm{CH}_{3} \mathrm{COO}^{-}, \mathrm{Cl}^{-}, \mathrm{CN}^{-}, \mathrm{CO}_{3}^{2-}, \mathrm{Cr}_{2} \mathrm{O}_{7}^{2-}$, $\mathrm{F}^{-}, \mathrm{HPO}_{4}^{2-}, \mathrm{HSO}_{3}^{-}, \mathrm{I}^{-}, \mathrm{NO}_{2}^{-}, \mathrm{NO}_{3}^{-}, \mathrm{OH}^{-}, \mathrm{SCN}^{-}$, and $\mathrm{SO}^{2-}$ at $350 \mathrm{~nm}$ (Figure 2). The spectra were instantly recorded after ion addition to Lansoprazole, upon absorbance between 200 and
$750 \mathrm{~nm}$, which strongly increased at $300-700 \mathrm{~nm}$ in the presence of carbonate ion. Upon adding carbonate ion to Lansoprazole, distinct spectral changes were induced, and a red-shift in the absorbance spectra was observed, while the other ions display no tangible changes along with the color change from colorless to yellow. These results show that Lansoprazole can be attended as a naked-eye $\mathrm{CO}_{3}^{2-}$ detector.

\section{Interfering Anions}

To investigate the selectivity of the prepared probe, the consistent mixtures of target ions and common interfering anions were correspondingly checked, and the results are represented in Figure 3. The absorbance spectra of chemosensor $\mathbf{L}$ were monitored in $\mathrm{CO}_{3}^{2-}$ ion and equivalent amounts of competing anions. The $\mathrm{CO}_{3}^{2-}$ ion created a significant red shift in Lansoprazole's UV-Vis spectra than other ions, as shown in Figure 3.

To determine the influence of other anions on the detection of carbonate anion in ethanol, different anions with a concentration of $0.01 \mathrm{M}$ were added to the Lansoprazole $\left(1 \times 10^{-4} \mathrm{~mol} \mathrm{~L}^{-1}\right)$ containing $\mathrm{CO}_{3}^{2-}\left(1 \times 10^{-2} \mathrm{~mol} \mathrm{~L}^{-1}\right)$. It was exhibited that other anions under experiment did not interfere with the detection of carbonate ion by receptor $\mathbf{L}$. The interfering ions induced small or no tangible changes in the absorbance system. As a result, this probe can be considered as a highly selective and reliable probe for $\mathrm{CO}_{3}^{2-}$ ion detection.

\section{Titration Experiments}

To evaluate the interacting potential of probe and $\mathrm{CO}_{3}^{2-}$, the titration experiments were performed (Figure 4).

Chemosensor $\mathbf{L}$ showed by the increase of carbonate ion concentration from 0 to $20 \mathrm{eq}$, all the absorption peaks at $480 \mathrm{~nm}$ were enhanced significantly. In the UV-Vis titration experiment, the red-shifted band triggered by carbonate ion continuously 


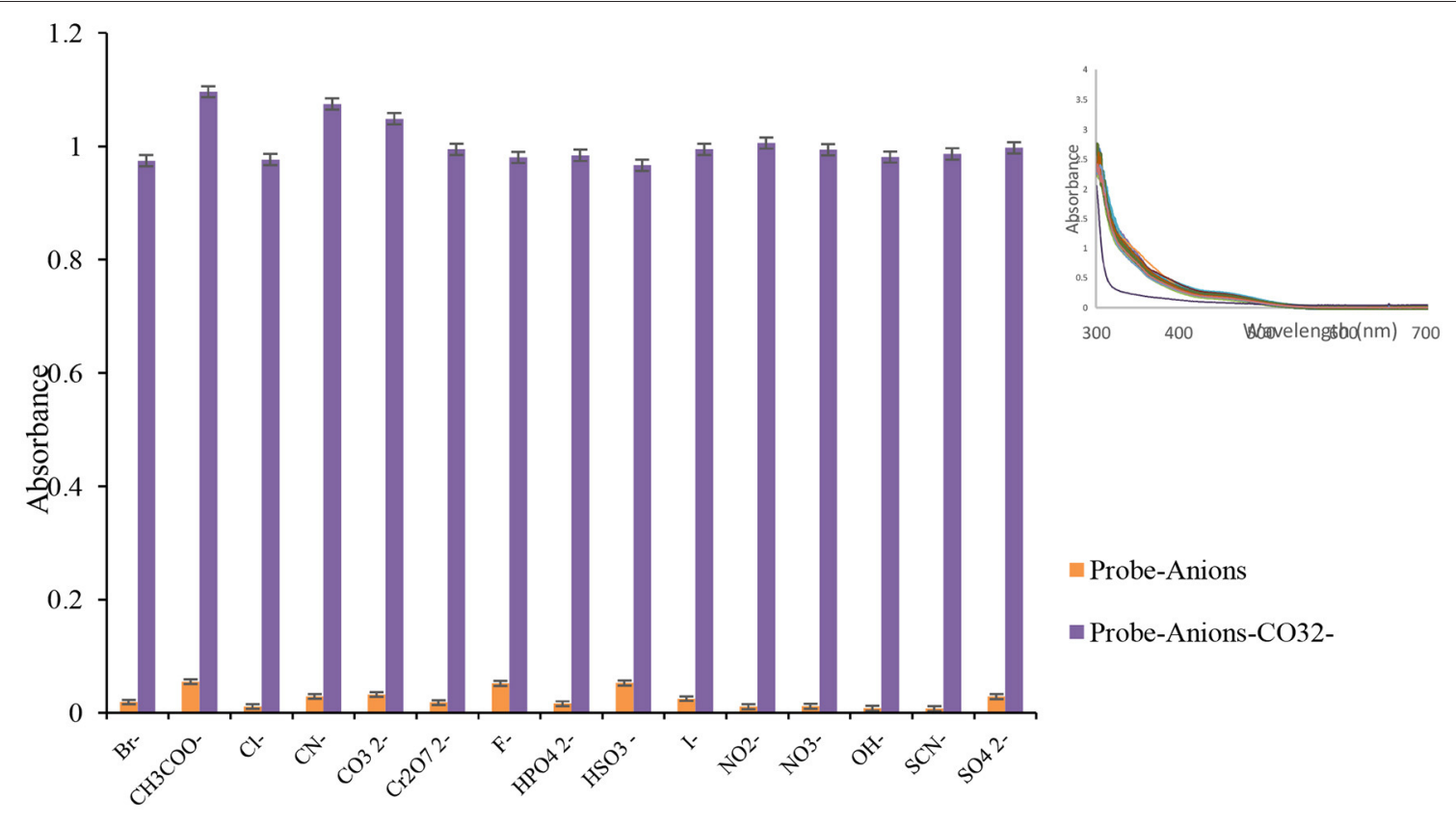

FIGURE 3 | The competitive experiment of chemosensor $\mathrm{L}(100 \mu \mathrm{L}, 0.01 \mathrm{M}) \mathrm{CO}_{3}^{2-}$ ion at $480 \mathrm{~nm}$ in the presence of other anions $(100 \mu \mathrm{L}, 0.01 \mathrm{M})$, and inset: absorbance spectra of probe solution $(1 \mathrm{~mL}, 0.001 \mathrm{M})$ after addition of various anions $(100 \mu \mathrm{L}, 0.01 \mathrm{M}) \cdot n=3, \mathrm{Sd}_{\text {average }}=1.86$

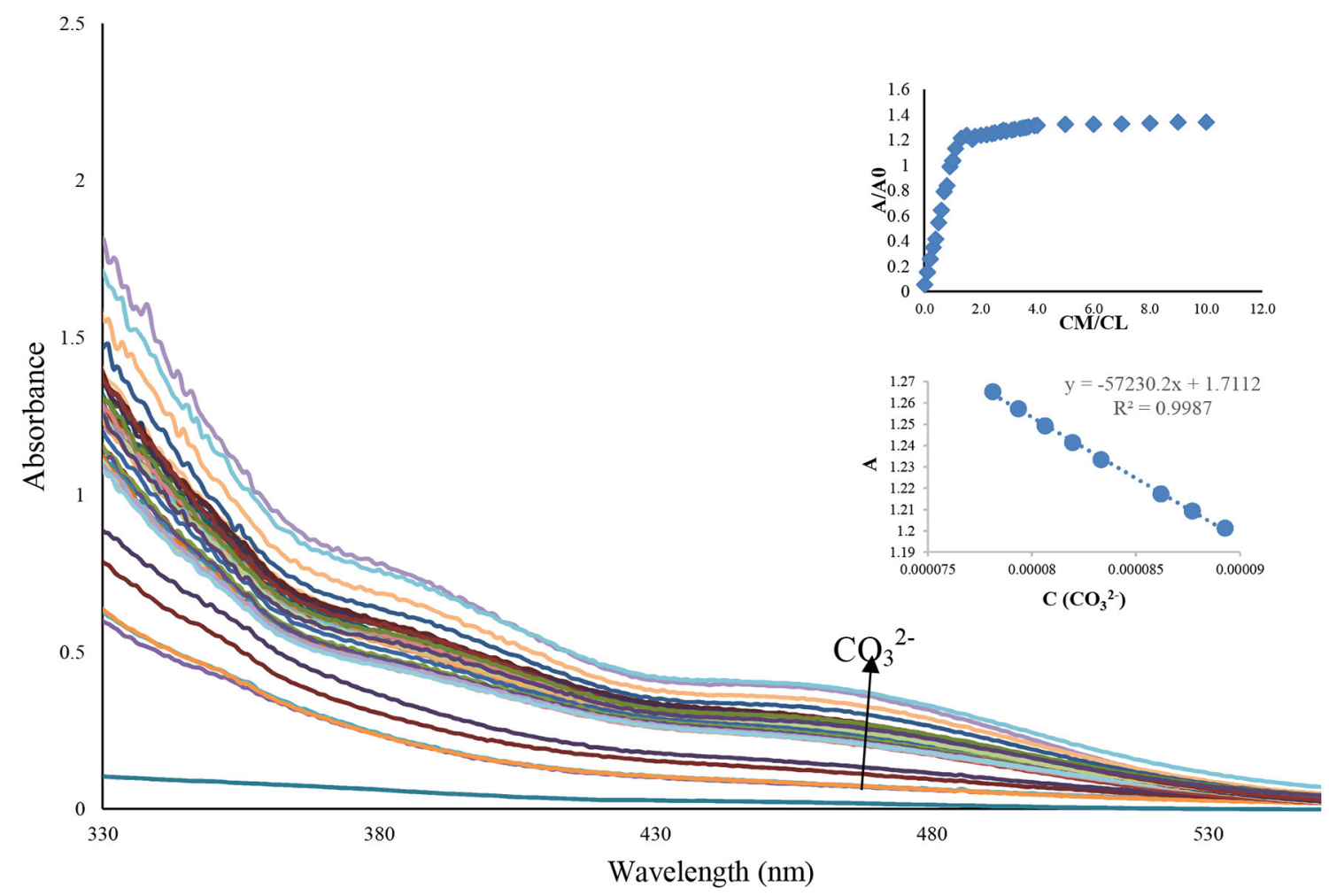

FIGURE 4 | Absorbance spectra of Benzimidazole $\mathbf{L}(1 \mathrm{~mL}, 0.0001 \mathrm{M})$ after adding the different concentration of an aqueous solution of $\mathrm{CO}_{3}^{2-}$ ion $(10-1,000 \mu \mathrm{L}$, $0.01 \mathrm{M}$ ), inset: the relationship between the concentration of $\mathrm{CO}_{3}^{2-}$ and maximum absorbance at $480 \mathrm{~nm}$. 
TABLE 1 | Absorption properties of chemosensor $L$ in various solvents.

\begin{tabular}{lc}
\hline Solvent & $\lambda_{\text {abs }}(\mathbf{n m})$ \\
\hline $\mathrm{MeOH}$ & 473 \\
Acetonitrile & 482 \\
$\mathrm{H}_{2} \mathrm{O}: \mathrm{EtOH}$ & 476 \\
$\mathrm{DMSO}$ & 485 \\
\hline
\end{tabular}

increases with the successive increment of carbonate ion (0-10 eq) into the chemosensor $\mathrm{L}$, as shown in Figure 4. The inset in Figure 4 is a plot of the UV-Vis absorption of chemosensor L. It can be seen that absorption increases through the increase of $\mathrm{CO}_{3}^{2-}$ from 0 to $10 \mu \mathrm{M}$. When the concentration of $\mathrm{CO}_{3}^{2-}$ is larger than $100 \mu \mathrm{M}$, the absorption spectra almost remains unchanged. The detection limit of Lansoprazole for $\mathrm{CO}_{3}^{2-}$ was determined to be $0.57 \times 10^{-6} \mathrm{M}$ with a linear range of concentration to be $0-10 \mu \mathrm{M}$. The apparent bathochromic shift that occurred by carbonate ion led us to propose that the $\pi$ conjugate system of chemosensor $\mathbf{L}$ underwent intramolecular charge transfer from donor to acceptor by excitation through the deprotonation of sensor $\mathbf{L}$ by $\mathrm{CO}_{3}^{2-}$ ion. Lansoprazole's ratiometric response on carbonate addition indicated a 1:1 stoichiometric adduct of chemosensor $\mathbf{L}$ and carbonate ion (Figure 4). After concentration enhancement of $\mathrm{CO}_{3}^{2-}$ ion from 100 to $1,000 \mu \mathrm{M}$, the absorbance reaches a plateau at $390 \mathrm{~nm}$, while the absorbance is steadily (insets in Figure 4). To identify the charge transfer of chemosensor $\mathbf{L}$, we have checked the change of its absorption spectra in different solvents such as DMSO, $\mathrm{MeOH}, \mathrm{H}_{2} \mathrm{O}: \mathrm{EtOH}$, and Acetonitrile since it has been reported that the dipole of solvents can relax the charge transfer excited by polar solvents. As summarized in Table 1, the absorption spectra of chemosensor L featured a marginal absorption red-shift maximum at $11 \mathrm{~nm}$, which indicate an apparent solvent dependence of the absorption band. To confirm whether the color change and absorbance change occur due to charge transfer due to the deprotonation mechanism. Therefore, the solvatochromic behavior demonstrated the occurrence of the charge transfer transition in chemosensor $\mathbf{L}$. The fact that the sensing of carbonate ion by receptor $\mathbf{L}$ does not depend on counter metal ion, established by a similar type of absorbance spectra demonstrated by $\mathbf{L}$ with potassium carbonate.

\section{Application of Probe $\mathbf{L}$}

To check the practical applications, the test kits were utilized to sense $\mathrm{CO}_{3}^{2-}$ among different competing anions. As shown in Figure 5, When the test kits coated with chemosensor $\mathbf{L}$ were added to different anion solutions, the distinctive color change was detected only with $\mathrm{CO}_{3}^{2-}$ in ethanol solution. Therefore, the test kits coated with the probe $\mathbf{L}$ solution would be convenient for detecting carbonate. These results depicted that chemosensor $\mathbf{L}$ could be a valuable practical chemosensor for the analysis of carbonate ions.

\section{Reversibility}

The reversibility of the receptor lansoprazole was performed by adding acetic acid and $\mathrm{Na}^{+}$binding agent. The addition of acetic acid to a mixture of chemosensor $\mathrm{L}$ and sodium carbonate resulted in the appearance of a peak at $480 \mathrm{~nm}$, which indicates the regeneration of the receptor $\mathrm{L}$. The absorption band at $480 \mathrm{~nm}$ was recovered by the addition of sodium carbonate, the same as the first. Such reversibility is vital for the fabrication of devices to sense the $\mathrm{CO}_{3}^{2-}$ ion (Figure 6).

\section{Theoretical Study}

The molecular orbital (MO) energy level and distribution of the Lansoprazole was carried out by density functional theory (DFT) calculation at the B3LYP/6-311+G(2d,2p) level (Ishtiaq et al., 2016; Iqbal et al., 2018; Isaac et al., 2018; Islam et al., 2018). As we can see from Figure 7, the electron clouds of $\mathrm{LUMO}+1, \mathrm{LUMO}+2$ level of energy for chemosensor $\mathbf{L}$ were mainly distributed on the pyridine, and for LUMO level cloud was distributed on the $\mathrm{C}=\mathrm{N}$ bond of benzimidazole group. While the electron density of HOMO was delocalized over the sulfoxide group, the electron density of HOMO-1 was almost populated on the $\mathrm{C}=\mathrm{N}$ bond of the pyridine group, and the electron clouds of HOMO-2 were concentrated on the nitrogen in a five-membered ring. Therefore, transitions between all levels of energy had occurred for Lansoprazole. These levels of energies are much accessible for electron transfer.

Furthermore, the orbital energies of Lansoprazole were sequentially increased (Figure 7B), which indicates the easy coordination ability of chemosensor toward ion. Also, the electron density of $\mathrm{LUMO}+2$ and $\mathrm{HOMO}$ of complex $\mathrm{L}_{-} \mathrm{CO}_{3}^{2-}$ were mainly populated on the benzimidazole group (Figure 7B). While the electron density of LUMO+1 and HOMO-2 were gathered together in the pyridine ring, the electron density of LUMO, HOMO-1 were mainly concentrated on the sulfoxide group. The distribution and $\mathrm{MO}$ level of energy indicated the complexation of Lansoprazole and $\mathrm{CO}_{3}^{2-}$ ion through intermolecular charge transfer (CT). Notably, the calculated energy gaps between HOMO and LUMO decreased, respectively: $1.99<3.32$ for probe $\mathbf{L}$ and $\mathbf{L}-\mathrm{CO}_{3}^{2-}$ complex. Such lowering HOMO-LUMO gaps of Lansoprazole upon $\mathrm{CO}_{3}^{2-}$ complexation attributed to the electron distributions after bindings. The electron redistributions resulted in the absorbance change with subsequent shifts.

Computations on the probe $\mathbf{L}$, both after and before combination with $\mathrm{CO}_{3}^{2-}$ were investigated in order to get the close approach toward the possible binding mechanism. The optimized structures and a schematic representation of SCF counters have been shown for probe $\mathbf{L}$ and $\mathbf{L}-\mathrm{CO}_{3}^{2-}$ complex in Figure 8. The SCF counter showed that the chemosensor L had a uniform electron cloud scattering throughout the molecule and some active sites on sulfoxide, pyridine, and benzimidazole groups shown in Figure 6. Otherwise, in $\mathrm{L}-\mathrm{CO}_{3}^{2-}$ complex, a strong electron distribution was changed entirely, and the electron density distribution is completely altering from chemosensor L. Moreover, a strong interaction was exhibited between the benzimidazole group, $\mathrm{CH}_{2}$ group linked to $\mathrm{CF}_{3}$, and $\mathrm{CO}_{3}^{2-}$ anion. 


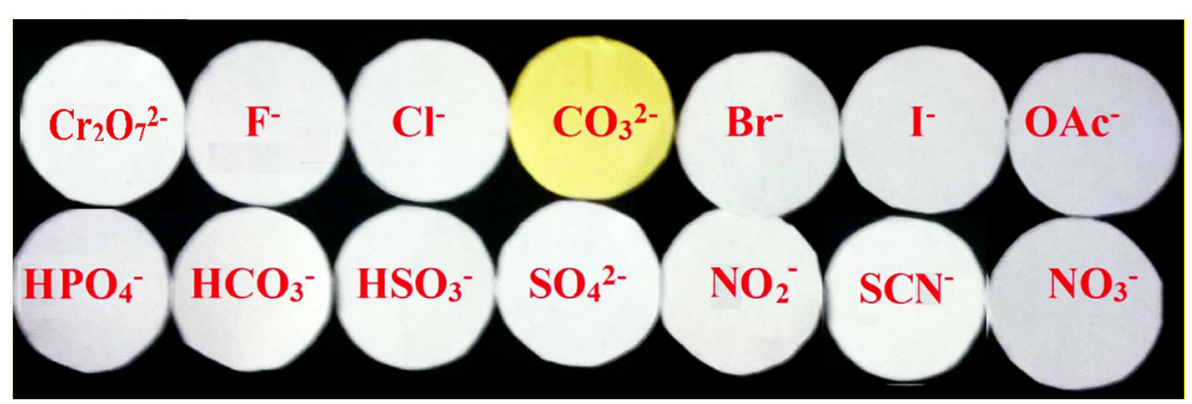

FIGURE 5 | Photographs of the lansoprazole test kits $(0.5 \mathrm{mM})$ in order to detect $\mathrm{CO}_{3}^{2-}$ rather than other anions.

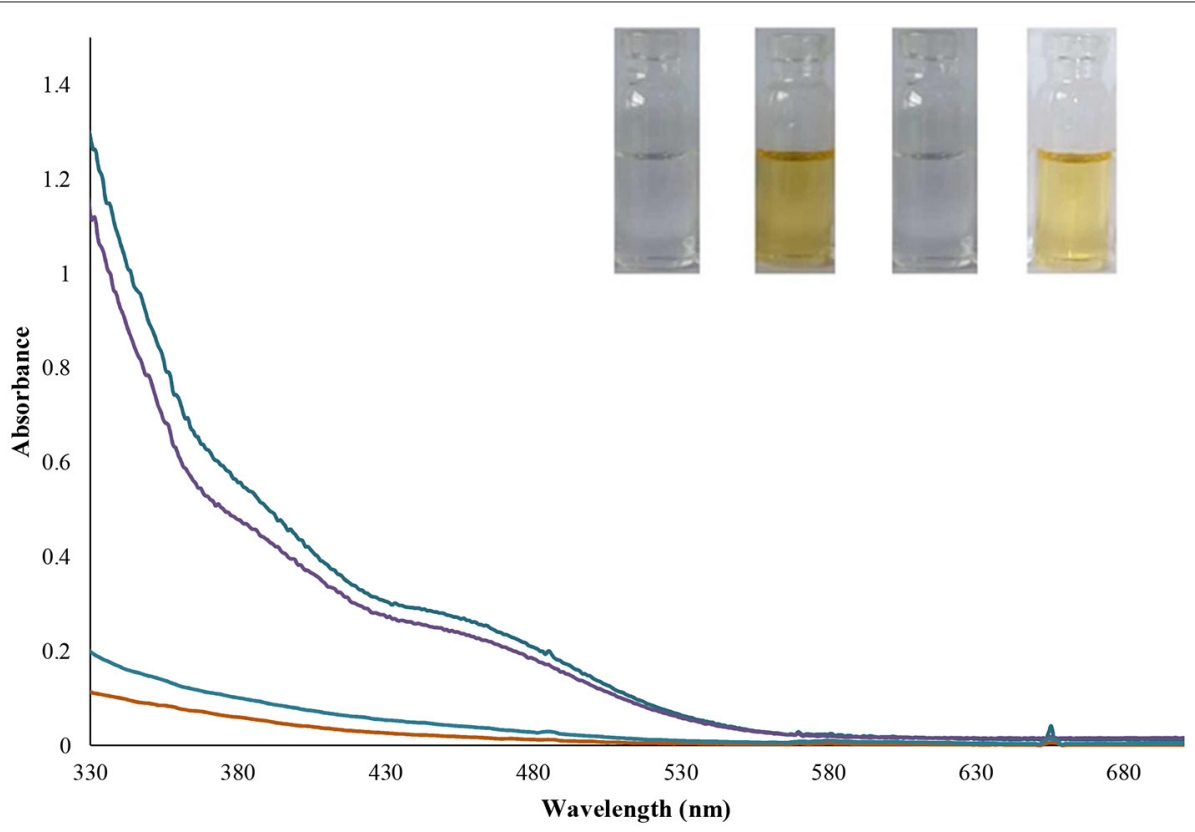

FIGURE 6 | Reversibility test of chemosensor $L$ with acetic acid and sodium carbonate addition.

\section{Mulliken Charge Analysis}

Mulliken charge analysis was done through the calculation of the electron population for an individual atom. In chemosensor $\mathbf{L}$, the positive charge strongly found at S10, and moderately on C4, $\mathrm{C} 15$, and $\mathrm{C} 22$. The positive charge for the sulfur atom is because of electronegative atom $\mathrm{O}$ and $\mathrm{C}$ atom because of conjugated structure in the closest sites. The $\mathrm{O} 19$ atom has negative charges; C9 atom attached to $\mathrm{S}$ atom possesses a negative charge. MEP is allied to electron density and is a very suitable descriptor in acceptor sites for the nucleophilic and electrophilic attack as hydrogen bonding interactions. The positive electron density localized on the $\mathrm{S}$ atom and $\mathrm{C}$ atoms of benzimidazole and pyridine structures.

\section{Mechanism of Sensing}

To elucidate the interaction process of the chemosensor $\mathbf{L}$ and $\mathrm{CO}_{3}^{2-}$ ion, the Gibbs free energy profile of the reaction is calculated, displayed in Figure 9. We choose the reactant energies as the zero-point energy, and the data are listed in Figure 9. The formation of the intermediate complex is carried out by absorbing the energy of $3.2 \mathrm{kcal} / \mathrm{mol}$ and a transition states is found by TS theory, which is located at the cleavage of C6, C10, and $\mathrm{S} 8$ and the formation of $\mathrm{CO}_{3}^{2-}$-S and $\mathrm{CO}_{3}^{2-}$-C bonds. In addition, through the IRC calculation, we have confirmed that the transition state is indeed linked to the intermediate and product. The reaction barrier from the intermediate complex to the TS is $10.1 \mathrm{kcal} / \mathrm{mol}$, which is relatively low. The low reaction barrier means that the chemosensor $\mathbf{L}$ has a favorable response speed to $\mathrm{CO}_{3}^{2-}$ ion.

To explore the selectivity of the chemosensor $\mathrm{L}$ to carbonate, the interaction energies between chemosensor $\mathrm{L}$ and different anions have been studied, which are listed in Table 2. We calculated the interaction energies based on the $E_{\text {int }}=E_{L}$ $+E_{\text {anion }}-E_{p}$. As seen in Table 2, the interaction energy between 


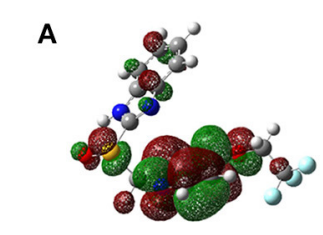

$\mathrm{LUMO}+2 \quad \mathrm{E}=-4.00 \mathrm{eV}$

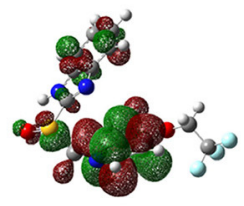

$\mathrm{LUMO}+1$

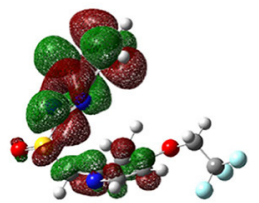

LUMO E=-4.61 eV

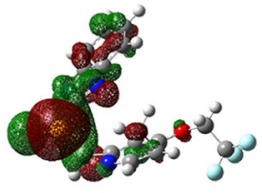

HOMO

$\mathrm{E}=-7.93 \mathrm{eV}$

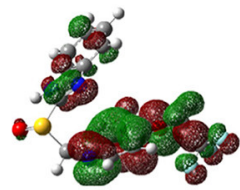

HOMO-1 $\quad \mathrm{E}=-8.81 \mathrm{eV}$

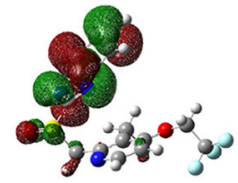

HOMO-2 $\quad \mathrm{E}=-9.03 \mathrm{eV}$

$\Delta \mathrm{E}=3.32 \mathrm{eV}$
B

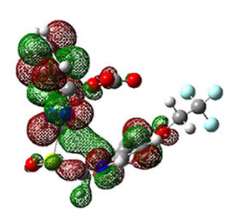

$\mathrm{LUMO}+2 \quad \mathrm{E}=-3.71 \mathrm{eV}$

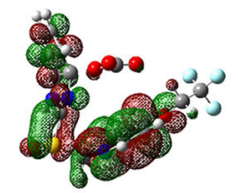

LUMO+1 E=-4.04 eV

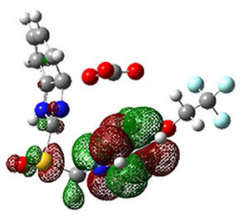

LUMO $\quad E=-4.31 \mathrm{eV}$

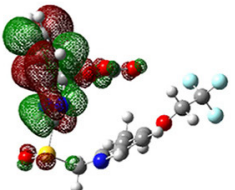

HOMO $\quad \mathrm{E}=-6.30 \mathrm{eV}$

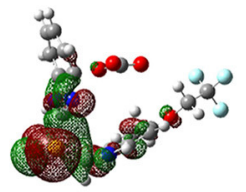

HOMO-1 E=-7.43 eV

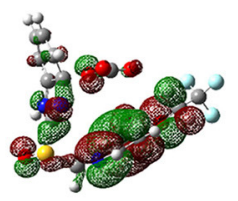

HOMO-2 $\mathrm{E}=-8.74 \mathrm{eV}$

$\Delta \mathrm{E}=1.99 \mathrm{eV}$

FIGURE 7 | (A) Corresponding orbital electron distribution $\mathrm{LUMO}+2$, LUMO+, LUMO, HOMO, HOMO-1, and HOMO-2 of (A) chemosensor $\mathbf{L}$ and (B) complex $\mathrm{L}_{-} \mathrm{CO}_{3}^{2-}$.

$\mathbf{L}$ and $\mathrm{CO}_{3}^{2-}$ is the largest one among these energies. The considerable interaction energy confirms the excellent selectivity of the chemosensor $\mathbf{L}$ for $\mathrm{CO}_{3}^{2-}$.

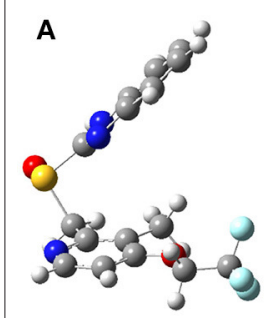

C

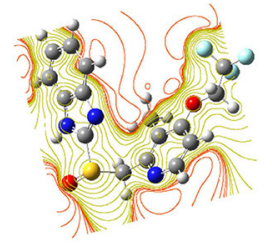

B

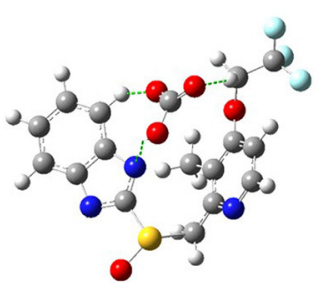

D

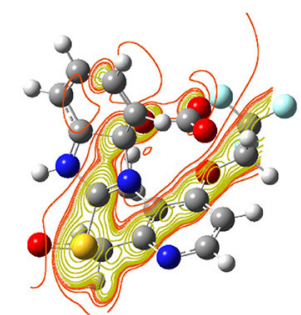

FIGURE 8 | Optimized geometries of chemosensor (A) L, and (B) L- $\mathrm{CO}_{3}{ }^{2-}$ and also the SCF counter of (C) $\mathbf{L}$ and (D) $\mathbf{L}-\mathrm{CO}_{3}^{2-}$.

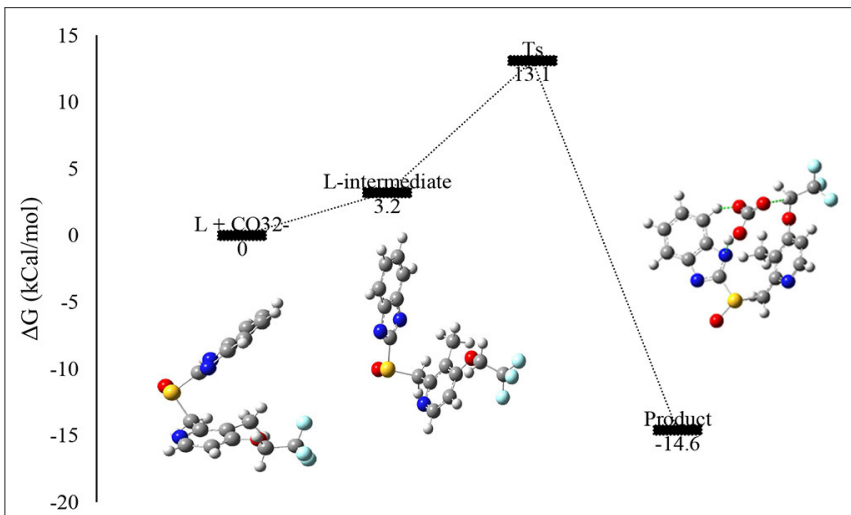

FIGURE 9 | Free energy profile for the nucleophilic addition reaction of chemosensor $\mathbf{L}$ and $\mathrm{CO}_{3}^{2-}$.

\section{CONCLUSION}

In summary, the receptor Lansoprazole has shown the colorimetric response in the presence of $\mathrm{CO}_{3}^{2-}$ ion in ethanol solution with high degree of selectivity. This naked-eye colorimetric chemosensor for the detection of carbonate ion revealed a low detection limit $0.57 \mu \mathrm{M}$. It has excellent sensitivity and selectivity to sense $\mathrm{CO}_{3}^{2-}$ by changes in absorption over a variety of anions. Furthermore, the binding mechanism of the Lansoprazole toward $\mathrm{CO}_{3}^{2-}$ ions was investigated by DFT calculation. The structural parameter analysis indicates that the intramolecular bonding in chemosensor $\mathbf{L}$ and the $\mathrm{CO}_{3}^{2-}$ ion, which induce the intramolecular proton transfer. The Ts calculation demonstrates that the reaction between $\mathrm{L}$ and $\mathrm{CO}_{3}^{2-}$ need overcoming a small energy barrier $(10.1 \mathrm{kcal} / \mathrm{mol})$ and the interaction energy $(94.9 \mathrm{~kJ} / \mathrm{mol})$, both of which confirmed that chemosensor L has high sensitivity and selectivity to $\mathrm{CO}_{3}^{2-}$ ion. The experiments' results and theoretical works beside each other 
TABLE 2 | Calculated interaction energies for the chemosensor $\mathbf{L}$ with different anions.

\begin{tabular}{lc}
\hline Anions & $\mathbf{E}_{\text {int }}(\mathbf{k J} / \mathbf{m o l})$ \\
\hline $\mathrm{CO}_{3}^{2-}$ & 94.9 \\
$\mathrm{~F}^{-}$ & 72.6 \\
$\mathrm{Cl}^{-}$ & 34.1 \\
$\mathrm{Br}^{-}$ & 22.9 \\
$\mathrm{I-}$ & 36.7 \\
$\mathrm{SCN}^{-}$ & 22.3 \\
$\mathrm{AcO}^{-}$ & 29.5 \\
$\mathrm{NO}_{3}^{-}$ & 11.3 \\
$\mathrm{NO}_{2}^{-}$ & 17.5 \\
$\mathrm{Cr}_{2} \mathrm{O}_{7}^{2-}$ & 40.9 \\
$\mathrm{HPO}_{4}^{-}$ & 14.2 \\
$\mathrm{SO}_{4}^{2-}$ & 38.6 \\
$\mathrm{HSO}_{3}^{-}$ & 30.7 \\
$\mathrm{OH}^{-}$ & 69.1 \\
\hline
\end{tabular}

can be sued to the chemosensor's development and clarify the mechanism of sensing metal ions, anions, and drug molecules.

\section{DATA AVAILABILITY STATEMENT}

The original contributions presented in the study are included in the article/Supplementary Materials, further inquiries can be directed to the corresponding author/s.

\section{AUTHOR CONTRIBUTIONS}

MD: visualization, formal analysis, computational study, analysis data, and writing original draft. GM: funding acquisition, methodology, supervision, and writing - review and editing. SB: visualization, methodology, analysis data, and writing-review and editing. JG: methodology and writing-review and editing. AB: writing-review and editing. All authors contributed to the article and approved the submitted version.

\section{ACKNOWLEDGMENTS}

The authors are sincerely acknowledging the financial support provided for this study by the Research Council of Alzahra University and the University of Tehran. The numerical calculations reported in this paper were fully performed at SANCAR, Turkish-German University System and Nodes of Computational Applications and Research.

\section{SUPPLEMENTARY MATERIAL}

The Supplementary Material for this article can be found online at: https://www.frontiersin.org/articles/10.3389/fchem. 2020.626472/full\#supplementary-material

\section{REFERENCES}

Abramova, N., Levichev, S., and Bratov, A. (2010). The influence of $\mathrm{CO}_{2}$ on ISFETs with polymer membranes and characterization of a carbonate ion sensor. Talanta 81, 1750-1754. doi: 10.1016/j.talanta.2010.03.034

Ahmadi, T., Bahar, S., Mohammadi Ziarani, G., and Badiei, A. (2019). Formation of functionalized silica-based nanoparticles and their application for extraction and determination of $\mathrm{Hg}$ (II) ion in fish samples. Food Chem. 300:125180. doi: 10.1016/j.foodchem.2019.125180

Andzelm, J., Klmel, C., and Klamt, A. (1995). Incorporation of solvent effects into density functional calculations of molecular energies and geometries. J. Chem. Phys. 103:9312. doi: 10.1063/1.469990

Arab, R., Hajiaghababaei, L., Badiei, A., Karimi, M., Ganjali, M. R., and Mohammadi Ziarani, G. (2019). 8-Hydroxyquinoline grafted nanoporous SBA15 as a novel solid phase extractor for preconcentration of trace amount of Copper. Int. J. Nano Dimens. 10, 340-349.

Barone, V., and Cossi, M. (1998). Quantum calculation of molecular energies and energy gradients in solution by a conductor solvent model. J. Phys. Chem. A 102, 1995-2001. doi: 10.1021/jp9716997

Burt, E. E., and Rau, A. H. (1994). The determination of the level of bicarbonate, carbonate, or carbon dioxide in aqueous solutions. Drug Dev. Ind. Pharm. 20, 2955-2964. doi: 10.3109/03639049409041960

Choi, Y. S., Lvova, L., Shin, J. H., Oh, S. H., Lee, C. S., Kim, B. H., et al. (2002). Determination of oceanic carbon dioxide using a carbonate-selective electrode. Anal. Chem. 74, 2435-2440. doi: 10.1021/ac0108459

Cossi, M., Rega, N., Scalmani, G., and Barone, V. (2003). Energies, structures, and electronic properties of molecules in solution with the C-PCM solvation model. J. Comput. Chem. 24, 669-681. doi: 10.1002/jcc.10189

Darroudi, M., Mohammadi Ziarani, G., Ghasemi, J. B., and Badiei, A. (2020). Acenaphtoquinoxaline as a selective fluorescent sensor for $\mathrm{Hg}$

(II) detection: experimental and theoretical studies. Heliyon 6:e04986. doi: 10.1016/j.heliyon.2020.e04986

Estrada-Ortiz, N., Lopez-Gonzales, E., Woods, B., Stürup, S., De Graaf, I. A. M., Groothuis, G. M. M., et al. (2019). Ex vivo toxicological evaluation of experimental anticancer gold(i) complexes with lansoprazole-type ligands. Toxicol. Res. 8, 885-895. doi: 10.1039/c9tx00149b

Fabbrizzi, L., Leone, A., and Taglietti, A. (2001). A chemosensing ensemble for selective carbonate detection in water based on metal-ligand interactions. Angew. Chem. Int. Ed. 40, 3066-3069. doi: 10.1002/1521-3773(20010817)40:16<3066::AID-ANIE3066>3.0.CO;2-0

Fabbrizzi, L., Licchelli, M., and Taglietti, A. (2003). The design of fluorescent sensors for anions: taking profit from the metal-ligand interaction and exploiting two distinct paradigms. J. Chem. Soc. Daltons Trans. 3, 3471-3479. doi: 10.1039/b304172g

García-Acosta, B., García, F., García, J. M., Martínez-Méñez, R., Sancenón, F., SanJosé, N., et al. (2007). Chromogenic signaling of hydrogen carbonate anion with pyrylium-containing polymers. Org. Lett. 9, 2429-2432. doi: 10.1021/ol0705191

Ghorai, A., Mondal, J., Chandra, R., and Patra, G. K. (2016a). A reversible fluorescent-colorimetric chemosensor based on a novel Schiff base for visual detection of CO32- in aqueous solution. RSC Adv. 6, 72185-72192. doi: 10.1039/c5ra24549d

Ghorai, A., Mondal, J., Chandra, R., and Patra, G. K. (2016b). A reversible fluorescent-colorimetric chemosensor based on a novel Schiff base for visual detection of CO32- in aqueous solution. RSC Adv. 6, 72185-72192.

Gremse, D. A. (2001). Lansoprazole: pharmacokinetics, pharmacodynamics and clinical uses. Expert Opin. Pharmacother. 2, 1663-1670. doi: $10.1517 / 14656566.2 .10 .1663$

Grimme, S. (2006). Semiempirical GGA-type density functional constructed with a long-range dispersion correction. J. Comput. Chem. 27, 1787-1799. doi: $10.1002 /$ jcc. 20495 
Han, C., Cui, Z., Zou, Z., Sabahaiti, T.ian, D., and Li, H. (2010). Urea-type ligandmodified CdSe quantum dots as a fluorescence "turn-on" sensor for CO32anions. Photochem. Photobiol. Sci. 9, 1269-1273. doi: 10.1039/c0pp00119h

Hay, P. J., and Wadt, W. R. (1985). Ab initio effective core potentials for molecular calculations. Potentials for the transition metal atoms Sc to Hg. J. Chem. Phys. 82, 270. doi: 10.1063/1.448799

He, L., Liu, C., and Xin, J. H. (2015). A novel turn-on colorimetric and fluorescent sensor for $\mathrm{Fe}^{3+}$ and $\mathrm{A}^{\mathrm{l}+}$ with solvent-dependent binding properties and its sequential response to carbonate. Sensors Actuators B Chem. 213, 181-187. doi: $10.1016 /$ j.snb.2015.02.060

Hennrich, G., Sonnenschein, H., and Resch-Genger, U. (2001). Fluorescent anion receptors with iminoylthiourea binding sites - Selective hydrogen bond mediated recognition of $\mathrm{CO}_{3}^{2-}, \mathrm{HCO}^{3-}$ and $\mathrm{HPO}_{4}^{2-}$. Tetrahedron Lett. 42, 2805-2808. doi: 10.1016/S0040-4039(01)00324-0

Iqbal, N., Ali, S. A., Munir, I., Khan, S., Ayub, K., Al-Rashida, M., et al. (2018). Acridinedione as selective flouride ion chemosensor: a detailed spectroscopic and quantum mechanical investigation. RSC Adv. 8, 1993-2003. doi: $10.1039 / \mathrm{c} 7 \mathrm{ra} 11974 \mathrm{~g}$

Isaac, I. O., Munir, I., Al-Rashida, M., Ali, S. A., Shafiq, Z., Islam, M., et al. (2018). Novel acridine-based thiosemicarbazones as "turn-on" chemosensors for selective recognition of fluoride anion: a spectroscopic and theoretical study. R. Soc. Open Sci. 5:180646. doi: 10.1098/rsos.180646

Ishtiaq, M., Munir, I., Al-Rashida, M., Maria, Ayub, K., Iqbal, J., et al. (2016). Novel quinoxaline based chemosensors with selective dual mode of action: Nucleophilic addition and host-guest type complex formation. RSC Adv. 6, 64009-64018. doi: 10.1039/c6ra14134j

Islam, M., Hameed, A., Ayub, K., Naseer, M. M., Hussain, J., Alharthy, R. D., et al. (2018). Receptor-spacer-fluorophore based coumarin-thiosemicarbazones as anion chemosensors with "turn on" response: spectroscopic and computational (DFT) studies. ChemistrySelect 3, 7633-7642. doi: 10.1002/slct.201801035

Jain, A. K., Gupta, V. K., and Raisoni, J. R. (2006). Anion recognition using newly synthesized hydrogen bonding diamide receptors: PVC based sensors for carbonate. Electrochim. Acta 52, 951-957. doi: 10.1016/j.electacta.2006.06.037

Jie, Q., and Guo-Zhu, J. (2013). Dielectric constant of polyhydric alcoholDMSO mixture solution at the microwave frequency. J. Phys. Chem. A 117, 12983-12989. doi: 10.1021/jp4082245

Kahriman, N., Gün, S., Gümrükçüoglu, A., Yayl,i, N., Ocak, Ü., and Ocak, M. (2019). Naked eye detection of carbonate, hydroxide, and cyanide ions with 1,4'-diazaflavonium bromides: a simple spectrophotometric method for cyanide determination. J. Heterocycl. Chem. 56, 2612-2618. doi: 10.1002/jhet.3669

Karimi, M., Badiei, A., Lashgari, N., and Mohammadi Ziarani, G. (2017). A chromotropic acid modified SBA-15 as a highly sensitive fluorescent probe for determination of $\mathrm{Fe}^{3+}$ and I- ions in water. J. Porous Mater. 25, 1-10. doi: 10.1007/s10934-017-0427-9

Karuk Elmas, S. N., Ozen, F., Koran, K., Gorgulu, A. O., Sadi, G., Yilmaz, I., et al. (2018). Selective and sensitive fluorescent and colorimetric chemosensor for detection of $\mathrm{CO}_{3}^{2}$ - anions in aqueous solution and living cells. Talanta 188, 614-622. doi: 10.1016/j.talanta.2018.06.036

Kaur, N., Singh, J., Dhaka, G., Rani, R., and Luxami, V. (2015). Benzothiazolebased chemosensor for $\mathrm{CN}^{-}$and $\mathrm{Cu}^{2+}$ : multi-logic operations within a single molecule. Supramol. Chem. 27, 453-459. doi: 10.1080/10610278.2014.982118

Klamt, A., and Schüürmann, G. (1993). COSMO: a new approach to dielectric screening in solvents with explicit expressions for the screening energy and its gradient. J. Chem. Soc. Perkin Trans. 2, 799-805. doi: 10.1039/P29930000799

Ko, Y. G., Na, W. S., Mayank, Singh, N., and Jang, D. O. (2019). Triazole-coupled benzimidazole-based fluorescent sensor for silver, bromide, and chloride ions in aqueous media. J. Fluoresc. 29, 945-952. doi: 10.1007/s10895-019-02407-y

Kondo, S., and Takai, R. (2013). Selective detection of dihydrogen phosphate anion by fluorescence change with tetraamide-based receptors bearing isoquinolyl and quinolyl moieties. Org. Lett. 15, 538-541. doi: 10.1021/ol3033626

Kordi, Z. K., Ziarani, G. M., Badiei, A., and Lashgari, N. (2019). Synthesis of 1,4dihydropyridine as a fluorescent and colorimetric chemosensor for detection of Fe 3+ ion. Sens. Lett. 17, 747-754. doi: 10.1166/sl.2019.4137

Lee, H. K., Oh, H., Nam, K. C., and Jeon, S. (2005). Urea-functionalized calix[4] arenes as carriers for carbonate-selective electrodes. Sensors Actuators B Chem. 106, 207-211. doi: 10.1016/j.snb.2004.07.032
Liu, C., Xing, Z., Liu, L., and Han, Z. B. (2020). Ultrasound-assisted synthesis of a benzimidazole-containing $\mathrm{Zn}$ (II) coordination polymer as highly effective Lewis acid catalyst for cycloaddition of epoxides with $\mathrm{CO}_{2}$. Inorg. Chem. Commun. 113:107812. doi: 10.1016/j.inoche.2020.107812

Liu, F., Ping, R., Gu, Y., Zhao, P., Liu, B., Gao, J., et al. (2020). Efficient one pot capture and conversion of $\mathrm{CO}_{2}$ into quinazoline-2,4 $(1 \mathrm{H}, 3 \mathrm{H})$-diones using triazolium-based ionic liquids. ACS Sustain. Chem. Eng. 8, 2910-2918. doi: 10.1021/acssuschemeng.9b07242

Liu, W., Lau, F., Liu, K., Wood, H. B., Zhou, G., Chen, Y., et al. (2011). Benzimidazolones: a new class of selective peroxisome proliferatoractivated receptor $\gamma(\operatorname{PPAR} \gamma)$ modulators. J. Med. Chem. 54, 8541-8554. doi: $10.1021 / \mathrm{jm} 201061 \mathrm{j}$

Luzar, A., and Stefan, J. (1990). Dielectric behaviour of DMSO-water mixtures. A hydrogen-bonding model. J. Mol. Liq. 46, 221-238. doi: 10.1016/0167-7322(90)80056-P

MacGregor, W. S. (1967). The chemical and physical properties of DMSO. Ann. N. Y. Acad. Sci. 141, 3-12. doi: 10.1111/j.1749-6632.1967.tb34860.x

Mahmudi, M., Shadjou, N., and Hasanzadeh, M. (2019). Synthesis and adsorption behavior of dendritic Fibrous Nano-silica (DFNS) grafted by d-penicillamine as an advanced nanomaterial for the removal of some metal ions from contaminated water. J. Electroanal. Chem. 848:113272. doi: 10.1016/j.jelechem.2019.113272

Maji, A., Pal, S., Lohar, S., Mukhopadhyay, S. K., and Chattopadhyay, P. (2017). A new turn-on benzimidazole-based greenish-yellow fluorescent sensor for $\mathrm{Zn} 2+$ ions at biological pH applicable in cell imaging. New J. Chem. 41, 7583-7590. doi: 10.1039/c7nj01821e

Meruva, R. K., and Meyerhoff, M. E. (1998). Catheter-Type sensor for potentiometric monitoring of oxygen, $\mathrm{pH}$ and carbon dioxide. Biosens. Bioelectron. 13, 201-212. doi: 10.1016/S0956-5663(97)0 0097-3

Miyashita, T., Shah, F. A., Harmon, J. W., Marti, G. P., Matsui, D., Okamoto, K., et al. (2013). Do proton pump inhibitors protect against cancer progression in GERD? Surg. Today 43, 831-837. doi: 10.1007/s00595-012-0395-2

Mobed, A., Baradaran, B., Guardia, M., de la, Agazadeh, M., Hasanzadeh, M., Rezaee, M. A., et al. (2019). Advances in detection of fastidious bacteria: from microscopic observation to molecular biosensors. TrAC Trends Anal. Chem. 113, 157-171. doi: 10.1016/j.trac.2019.02.012

Monforte, A. M., Rao, A., Logoteta, P., Ferro, S., De Luca, L., Barreca, M. L., et al. (2008). Novel N1-substituted 1,3-dihydro-2H-benzimidazol-2-ones as potent non-nucleoside reverse transcriptase inhibitors. Bioorg. Med. Chem. 16, 7429-7435. doi: 10.1016/j.bmc.2008.06.012

Morf, W. E., Seiler, K., Lehmann, B., Behringer, C., Hartman, K., and Simon, W. (1989). Carriers for chemical sensors: design features of optical sensors (optodes) based on selective chromoionophores. Pure Appl. Chem. 61, 1613-1618. doi: 10.1351/pac198961091613

Morikawa, Y., Nishiwaki, K., Suzuki, S., Yasaka, N., Okada, Y., and Nakanishi, I. (2020). A new chemosensor for cyanide in blood based on the Pd complex of 2-(5-bromo-2-pyridylazo)-5-[N-n -propyl- N -(3-sulfopropyl)amino]phenol. Analyst 145, 7759-7764. doi: 10.1039/D0AN01554G

Morris, R. V., Ruff, S. W., Gellert, R., Ming, D. W., Arvidson, R. E., Clark, B. C., et al. (2010). Identification of carbonate-rich outcrops on Mars by the spirit rover. Science 329, 421-424. doi: 10.1126/science.1189667

Mostarda, S., Maz, T. G., Piccinno, A., Cerra, B., and Banoglu, E. (2019). Optimisation by design of experiment of benzimidazol-2-one synthesis under flow conditions. Molecules 24, 2447. doi: 10.3390/molecules 24 132447

Movassagh, B., Rooh, H., and Bijanzadeh, H. R. (2013). A mild and highly efficient one-pot synthesis of 1,3,5-triaryl-2- pyrazolines. Chem. Heterocycl. Compd. 48, 1719-1721. doi: 10.1007/s10593-013-1199-z

Naderi, F., Orojloo, M., Jannesar, R., and Amani, S. (2019). Synthesis and spectroscopic studies of an azo-azomethine receptor for naked-eye detection of hydrogen carbonate ions in aqueous media. Polycycl. Aromat. Compd. 39, 1-15. doi: 10.1080/10406638.2019.1672201

Patel, U. B., Mehta, V. N., Kumar, M. A., and Kailasa, S. K. (2013). 4Aminothiophenol functionalized gold nanoparticles as colorimetric sensors for the detection of cobalt using UV-Visible spectrometry. Res. Chem. Intermed. 39, 771-779. doi: 10.1007/s11164-012-0773-9 
Patel, V., Bhatt, N., Bhatt, P., and Joshi, H. D. (2014). Synthesis and pharmacological evaluation of novel 1-(piperidin-4-yl)-1H- benzo[d]imidazol$2(3 \mathrm{H})$-one derivatives as potential antimicrobial agents. Med. Chem. Res. 23, 2133-2139. doi: 10.1007/s00044-013-0799-6

Reena, V., Suganya, S., and Velmathi, S. (2013). Synthesis and anion binding studies of azo-Schiff bases: selective colorimetric fluoride and acetate ion sensors. J. Fluor. Chem. 153, 89-95. doi: 10.1016/j.jfluchem.2013.05.010

Rice, L. B. (2008). Federal funding for the study of antimicrobial resistance in nosocomial pathogens: no ESKAPE. J. Infect. Dis. 197, 1079-1081. doi: $10.1086 / 533452$

Robert, M. (1990). 40 Sleep hacks. Fhigfd 11, 79-170.

Rouh, H., Liu, Y., Katakam, N., Pham, L., Zhu, Y. L., and Li, G. (2018). Synthesis of functionalized chromene and chroman derivatives via cesium carbonate promoted formal $[4+2]$ annulation of $2^{\prime}$-hydroxychalcones with allenoates. J. Org. Chem. 83, 15372-15379. doi: 10.1021/acs.joc.8b02627

Shin, J. M., and Kim, N. (2013). Pharmacokinetics and pharmacodynamics of the proton pump inhibitors. J. Neurogastroenterol. Motil. 19, 25-35. doi: 10.5056/jnm.2013.19.1.25

Shiravand, G., Badiei, A., Goldooz, H., Karimi, M., Ziarani, G. M., Faridbod, F., et al. (2018). A Fluorescent g-C3N4 nanosensor for detection of dichromate ions. Curr. Anal. Chem. 14. doi: 10.2174/1573411014666180627150248

Shiravand, G., Ghasemi, J. B., Badiei, A., and Mohammadi Ziarani, G. (2020). A dual-emission fluorescence probe for simultaneous quantification of $\mathrm{CN}$ - and Cr2O72- ions based on modified g-C3N4. J. Photochem. Photobiol. A Chem. 389, 112261-112269. doi: 10.1016/j.jphotochem.2019.112261

Singh, A., Mohan, M. R.,and Trivedi, D. (2019). Chemosensor based on hydrazinyl pyridine for selective detection of $\mathrm{F}$ ion in organic media and $\mathrm{CO}_{3}^{2-}$ ions in aqueous media: design, synthesis, characterization and practical application. ChemistrySelect 4, 14120-14131. doi: 10.1002/slct.201903670

Smith, E. D., Ariane Vinson, N., Zhong, D., Berrang, B. D., Catanzaro, J. L., Thomas, J. B., et al. (2008). A new synthesis of the ORL-1 antagonist 1-[(3R,4R)-1-cyclooctylmethyl-3-hydroxymethyl-4-piperidinyl]3-ethyl-1,3-dihydro-2H-benzimidazol-2-one (J-113397) and activity in a calcium mobilization assay. Bioorg. Med. Chem. 16, 822-829. doi: 10.1016/j.bmc.2007.10.023

Smyth, P., Gibson, T. J., Irvine, G., Black, G., Lavery, D., Semsarilar, M., et al. (2020). pH-Responsive benzaldehyde-functionalized PEG-based polymeric nanoparticles for drug delivery: effect of preparation method on morphology, dye encapsulation and attachment. Eur. Polym. J. 124, 109471-109482. doi: 10.1016/j.eurpolymj.2019.109471

Tang, L., Cai, M., Huang, Z., Zhong, K., Hou, S., Bian, Y., et al. (2013). Rapid and highly selective relay recognition of $\mathrm{Cu}(\mathrm{II})$ and sulfide ions by a simple benzimidazole-based fluorescent sensor in water. Sensors Actuators B Chem. 185, 188-194. doi: 10.1016/j.snb.2013.04.109

Tang, L., Zheng, Z., Huang, Z., Zhong, K., Bian, Y., and Nandhakumar, R. (2015). Multi-analyte, ratiometric and relay recognition of a 2,5-diphenyl-1,3,4oxadiazole-based fluorescent sensor through modulating ESIPT. RSC Adv. 5, 10505-10511. doi: 10.1039/c4ra16347h

Tas, A. C. (2009). Monodisperse calcium carbonate microtablets forming at $70^{\circ} \mathrm{C}$

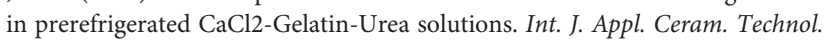
6, 53-59. doi: 10.1111/j.1744-7402.2008.02252.x

Tavallali, H., Deilamy-Rad, G., Parhami, A., and Lohrasbi, S. (2016). A novel and simple fluorescent and colorimetric primary chemosensor based on Congo-Red for sulfite and resultant complex as secondary fluorescent chemosensor towards carbonate ions: fluorescent probe mimicking INHIBIT logic gate. Talanta 149, 168-177. doi: 10.1016/j.talanta.2015.11.057

Tavallali, H., Karimi, M. A., Parhami, A., and Peykarimah, P. (2019). Novel use of calmagite as a fast and easy colorimetric anion chemosensor and solidstate sensor for carbonate ion in running water. Int. J. Environ. Anal. Chem. doi: $10.1080 / 03067319.2019 .1691182$

Tian, Z., and Li, D. (2020). The position effect of nitro group on the anion sensing performance of benzimidazole-naphthalimide derivatives. Res. Chem. Intermed. 46, 4659-4671. doi: 10.1007/s11164-020-04228-2
Tsukada, K., Miyahara, Y., Shibata, Y., and Miyagi, H. (1990). An integrated chemical sensor with multiple ion and gas sensors. Sensors Actuators B. Chem. 2, 291-295. doi: 10.1016/0925-4005(90)80156-T

Vaněk, J., Lubal, P., Hermann, P., and Anzenbacher, P. (2013). Luminescent sensor for carbonate ion based on lanthanide(III) complexes of 1,4,7,10tetraazacyclododecane-1,4,7-triacetic acid (DO3A). J. Fluoresc. 23, 57-69. doi: 10.1007/s10895-012-1116-3

Velmurugan, K., Vickram, R., Karthick, R., Jipsa, C. V., Suresh, S., Prabakaran, G., et al. (2020). Binol diuryl dipyrene fluorescent probe: Dual detection of silver and carbonate ions and its bioimaging applications. J. Photochem. Photobiol. A Chem. 401:112737. doi: 10.1016/j.jphotochem.2020.112737

Wasim, F., Kosar, N., Mahmood, T., and Ayub, K. (2018). Sensor applications of polypyrrole for oxynitrogen analytes: a DFT study. J. Mol. Model. 24, 1-14. doi: 10.1007/s00894-018-3843-0

Xu, N., Yang, C., Gan, X., Wei, S., and Ji, Z. (2013). Synthesis of 1-isopropyl-3-acyl5-methyl-benzimidazolone derivatives and their antimicrobial activity. Int. $J$. Mol. Sci. 14, 6790-6804. doi: 10.3390/ijms 14046790

Xu, X., Liu, P., Lesser, A., Sirois, L. E., Wender, P. A., and Houk, K. N. (2012). Ligand effects on rates and regioselectivities of $\mathrm{Rh}(\mathrm{I})$-catalyzed $(5+2)$ cycloadditions: a computational study of cyclooctadiene and dinaphthocyclooctatetraene as ligands. J. Am. Chem. Soc. 134, 11012-11025. doi: $10.1021 /$ ja3041724

Yu, M., Lee, C., Wang, M., and Tannock, I. F. (2015). Influence of the proton pump inhibitor lansoprazole on distribution and activity of doxorubicin in solid tumors. Cancer Sci. 106, 1438-1447. doi: 10.1111/cas.12756

Yu, M., Lin, H. H., Zhao, G., and Lin, H. H. (2007). A benzimidazole-based chromogenic anion receptor. J. Mol. Recogn. 20, 69-73. doi: 10.1002/jmr.810

Zhang, D., Jiang, X., Yang, H., Su, Z., Gao, E., Martinez, A., et al. (2013). Novel benzimidazolium-urea-based macrocyclic fluorescent sensors: synthesis, ratiometric sensing of H2PO4- and improvement of the anion binding performance via a synergistic binding strategy. Chem. Commun. 49, 6149-6151. doi: $10.1039 / \mathrm{c} 3 \mathrm{cc} 43184 \mathrm{c}$

Zhang, Y., and Yu, X. (2017). Colorimetric and electrochemical sensing for fluoride anion by ferrocenyl-based imidazole compound with electron donor-acceptor structure. Res. Chem. Intermed. 43, 1099-1105. doi: 10.1007/s11164-016-2685-6

Zhao, H., Park, S. J., Shi, F., Fu, Y., Battaglia, V., Ross, P. N., et al. (2014). Propylene carbonate (PC)-based electrolytes with high coulombic efficiency for lithiumion batteries. J. Electrochem. Soc. 161, A194-A200. doi: 10.1149/2.095401jes

Zheng, Z. B., Duan, Z. M., Ma, Y. Y., and Wang, K. Z. (2013). Highly sensitive and selective difunctional ruthenium(II) complex-based chemosensor for dihydrogen phosphate anion and ferrous cation. Inorg. Chem. 52, 2306-2316. doi: $10.1021 /$ ic $301555 \mathrm{r}$

Zhong, K., Zhou, X., Hou, R., Zhou, P., Hou, S., Bian, Y., et al. (2014). A watersoluble highly sensitive and selective fluorescent sensor for $\mathrm{Hg}^{2+}$ based on 2-(2-(8-hydroxyquinolin)-yl)benzimidazole via ligand-to-metal charge transfer (LMCT). RSC Adv. 4, 16612-16617. doi: 10.1039/c4ra00060a

Zhukova, N. A., and Mamedov, V. A. (2017). Advances in the synthesis of benzimidazol-2-ones. Russ. Chem. Rev. 86, 968-997. doi: 10.1070/rcr4749

Zougagh, M., Ríos, A., and Valcárcel, M. (2005). Direct determination of total carbonate salts in soil samples by continuous-flow piezoelectric detection. Talanta 65, 29-35. doi: 10.1016/j.talanta.2004.05.010

Conflict of Interest: The authors declare that the research was conducted in the absence of any commercial or financial relationships that could be construed as a potential conflict of interest.

Copyright (ㄷ 2021 Darroudi, Mohammadi Ziarani, Bahar, Ghasemi and Badiei. This is an open-access article distributed under the terms of the Creative Commons Attribution License (CC BY). The use, distribution or reproduction in other forums is permitted, provided the original author(s) and the copyright owner(s) are credited and that the original publication in this journal is cited, in accordance with accepted academic practice. No use, distribution or reproduction is permitted which does not comply with these terms. 